\title{
TRAINING OF UNDERGRADUATE PRESCHOOL TEACHERS IN MONTESSORI EDUCATION IN SLOVAKIA AND THE CZECH REPUBLIC
}

\begin{abstract}
The paper presents a description and comparison of the undergraduate student teacher training and kindergarten teacher continuing education in the Montessori Method of Education encompassed in formal education in Slovakia and the Czech Republic. The theoretical part of the paper aims at depicting Montessori education, still an attractive pedagogical direction in both countries, in a thorough, unconventional and innovative way. Even though Montessori education has been rooted worldwide for centuries, in Slovakia and the Czech Republic it presents relatively new alternative education, considering that an integrated school system, introduced in these countries in 1948 and lasting almost to the end of $20^{\text {th }}$ century, did not allow the use of other alternatives in addition to the mainstream education. A description of (preschool) education in both countries and an analysis of kindergarten teacher's personality and his/her lesson plans are included in the theoretical part of the paper. The empirical part contains pedagogical research of qualitative design, conducted in Slovakia and the Czech Republic in order to identify and map the current state, level and possibilities of formal education of pre-service and in-service teachers in Slovak and Czech kindergartens.
\end{abstract}

Keywords: Montessori Education, Teacher Training, Kindergarten Teacher, Kindergarten.

\section{Contemporary Montessori education (Slovakia and the Czech Republic)}

Montessori education, as we state in our recent work (Slovacek \& Minova, 2017a, pp. 68-69), is "a pedocentric educational and training concept of the Italian doctor, pedagogue and thinker Maria Montessori, who focuses her attention on the holistic, non-violent, humanistic and natural development of the child. The basic framework of Montessori education is generally divided into five key learning areas: Practical life, Sensorial, Language, Mathematics, and Culture. It is a philosophical-pedagogical concept based on along-time study, observation and practical experiments. Its cornerstone is Montessori's belief that children learn best through experience. Among other things, the individual pace of the child's work and progress, freedom and a structured, prepared environment are stressed."

\footnotetext{
1 slovacekmatej@gmail.com

2 monika.minova@unipo.sk
} 
Matsumoto (2009, p. 314) defines Montessori education as follows: "An approach to early childhood and elementary education which assumes the child has an active will to learn and will learn in his or her own individual way and at his/her own pace if given the freedom to do so within a structured and protected environment. Individual freedom and choice with responsibility and practical limits are emphasized, and older children are urged to attempt cooperative projects as ways of learning".

According to our unpublished research from 2019, Slovak and Czech experts who deal with Montessori education and alternative approaches in education most often interpret Montessori education through the terms freedom, sensory education, prepared environment, and child (developmental psychology and his/her position in society). The most frequent concept, freedom, resonates probably because it is a significant feature distinguishing Montessori education from the traditional integrated school system that prevailed in the two countries in the past.

Currently in Slovakia, this educational concept is attractive for parents but also for professionals. The trend of the mentioned attractiveness and interest has an increasing tendency. There are a few facts to illustrate this tendency. The number of professional events organized on behalf of Montessori education is increasing. In 2014, the Faculty of Education at the University of Presov in Presov, in cooperation with the Emerka family leisure center, organized a professional seminar called Montessori in Formal and Informal Teacher Training. In 2018, the Faculty of Education at Matej Bel University in Banska Bystrica organized a twoday international symposium on behalf of Montessori education. Department of Primary Education at the Faculty of Education of Masaryk University in Brno, headed by Mgr. Petra Vystrcilova, Ph.D., implemented the research project Individualization in Primary Education Natural Learning with a Respectful Approach According to Montessori Education. The project lasted from $1 / 2018$ to $12 / 2018$.

Another aspect to consider is experimental verification and its results. Experimental verification of Montessori education in Slovakia was approved by the Ministry of Education, Science, Research and Sport of the Slovak Republic on 30/05/2011 with effect from 01/09/2011 (decision number: 2016-8672/15327:4-100B, 2016; source: www.statpedu.sk). It enabled to experimentally verify the educational program of Montessori pedagogical concept for preprimary education at the Private Maria Montessori Primary School with the Kindergarten, seated in Bratislava, Borinska 23. According to the evaluation report, the educational outcomes in all monitored areas of children's development reached a very good level. Based on the results of experimental verification, the implementation of the Montessori Method of Education and its elements in the educational process of pre-primary education in kindergartens listed in the network of schools and school facilities of the Slovak Republic was approved. At present, according to the Overview of Experimental Verifications in the School Year 2016/2017 (www.statpedu.sk), an experimental verification entitled ISCED 1 and ISCED 2 Maria Montessori Pedagogical Conception Program is carried out. The professional guarantor is the National Institute for Education, seated in Bratislava, Pluhova 8, and the project is being implemented in the Private Maria Montessori Primary School with the Kindergarten, seated in Bratislava, Borinska 23. The verification was approved on 09/06/2010 and the expected completion date is $31 / 08 / 2019$. The topic and goal of this experimental verification is the universal development of the child (motor, cognitive, emotional and social), as well as the support of the holistic development of the child's personality - the application of Montessori education focused on the child. The aim is to introduce the Montessori 
Method of Education into primary school teaching in Slovakia.

Slovacek and Minova (2017a; 2019), Kosova, Almasi Korenova and Cinova (2013), Kozelkova (2013), Zelina (2000), Zelinkova (1997), Rydl (2007; 1999) and Sebestova and Svarcova (1996) are the main authors of theoretical and practical works on Montessori education in Slovakia and the Czech Republic. In both countries, a two-dimensional curricular model of pre-primary education is applied in kindergartens. The state defines the compulsory State Educational Program and kindergartens can supplement it with their own focus and specifics. Through these adjustments in the School Educational Program it is possible to apply Montessori education in kindergartens listed in the network of schools and school facilities. Other possibilities were defined by Slovacek and Minova (2019): (1) using of Montessori education elements within educational projects in kindergarten, (2) equipping the school with Montessori didactic materials, (3) using of Montessori education within school organization (heterogeneous age groups etc.).

\section{Montessori pedagogy and neuropedagogy}

At present, neuropedagogy and neurodidactics comprise a prominent part of Slovak educational reality as a result of the natural need for the development and improvement of pedagogical science. According to Petlak, Valabik and Zajacova (2009, p. 11), neurodidactics and neuropedagogy deal with "the effect of neuroscientific knowledge on education and didactics and how teaching and learning can be adapted to this knowledge". In the context of Montessori education, but also in the context of education as such, the focus is put on the environment that we can provide for children and that reflects the knowledge of neuropedagogy and neurodidactics. The study of alternative pedagogy and neuropedagogy (and neurodidactics) brought us to the conclusion that the principles and "rules" for the organization of a brain-compatible environment (when teaching and learning) have already been defined by Montessori. Brain-compatible learning describes how "knowledge about the structure and function of the brain is transformed into an educational process." Such learning (and teaching) takes place, as mentioned above, in a brain-compatible environment. This term is associated with the ITI (Integrated Thematic Instruction) model by Kovalik and Olsen. They speak of six conditions of such an environment: (1) trust - security and safety, (2) meaningful content, (3) freedom of choice, (4) enough time, (5) enriched environment, and (6) immediate feedback (Zelina, 2000). Tothova, Kostrub and Ferkova (2017) also mention (7) cooperation, (8) perfect mastery, and (9) targeted movement.

\section{Montessori education and the NTC learning system}

The quality and effects of education, training and instruction by Montessori can also be demonstrated by the success of graduates and other contexts. Specifically, there appears to be a similarity between the principles and activities in Montessori education and the NTC (Nikola Tesla Center) learning system (Rajovic, 2018), which is based on research in the field of neurology, medicine and psychiatry. The activities of both the NTC learning system and Montessori education are: balance exercises (walking on an ellipse), exercises of fine motor skills and graphomotor skills (fastening and unfastening buttons, studs, patents, tying bows), assembling puzzles, building the Pink Tower, drawing and painting, kitchen work, table setting, food preparation, cleaning, recognition of abstract concepts (flags, planets, learning letters), sorting (animals), ordering (brown stairs, red bars ...), music education (bells ...) and the like. 


\section{Kindergartens and teachers in Slovakia and the Czech Republic}

Education can be understood as part of the (child's) personality development. Personality development is a process of qualitatively ascending changes in personality dispositions, which make the child/person ready for an active and quality life in a certain socio-cultural space (Lipnicka, 2011).

In her work, Montessori (2007) also focuses on education. She defines three stages of education:

1. A child receives the first stage of education between birth and the $6^{\text {th }}$ or $7^{\text {th }}$ year of age. Due to a number of transformations taking place during this important period, Montessori introduces the following subdivision: (1) the first two years; (2) 3-5 years; (3) $6^{\text {th }}$ and $7^{\text {th }}$ year. The child receives this stage of education primarily in the family and kindergarten (Children's House).

2. A person receives a second stage of education between the ages of seven and twelve. This stage immediately precedes puberty. In the legislative conditions of Slovakia and the Czech Republic, this stage takes place more or less in primary school. Montessori calls the changes in this stage of education metamorphoses.

3. The third stage of education comes at the age of twelve and ends with reaching the adulthood, at the age of 18 .

A conference of European ministers was held in Heidelberg on 1and 2March 2007. One of the areas discussed was the area entitled "Let's start strong - Boosting preschool education in Europe". The prevailing opinion is that education and care in preschool age is a public good that provides a child/person a good foundation and a start in life (Pajdlhauserova, 2007). Subsequently, on 22 May 2008, the Education Act was passed. Education in the Czech Republic is regulated and characterized by the Act on Preschool, Primary, Secondary, Higher Vocational and Other Education of 24 September 2004. Pre-primary education is compulsory for children from the age of 5 in the Czech Republic (at the age of 6 they start compulsory schooling in primary school). In Slovakia, this obligation will apply from January 2021 (at present only the attendance of primary school from the age of 6 is compulsory).

Minova (2012, p. 15) states that "kindergarten currently occupies an important place in a child's life. Children come to kindergarten from the home environment, which is a child's refuge. The main goal of kindergartens is to support the personal development of children within social-emotional, intellectual, physical, moral, and aesthetic dimensions, develop abilities and skills, and provide preconditions for further education." According to Syslova (2007), the philosophy of preschool education is maximum adaptation to the developmental, physiological, cognitive, social and emotional needs of children in this age group. To ensure that these specifics of the developmental period are fully respected in education. Children from 2 to 6 years of age take part in the educational process in kindergartens in both countries.

"Vocational training of preschool workers began in Slovakia in the $19^{\text {th }}$ century, initially in teacher training institutes. It was implemented in the form of two-year courses, then after merging with the training of primary school teachers in four-year courses. In the school year 1893/1894, the Institute for the Education of Child Caretakers was also opened in Presov. In 1899, the Institute was promoted to the Women Teachers' Institute by a decree of the 
Hungarian Minister for School and Religious Affairs, where the teaching of caretakers and teachers of national schools merged. The Women Teachers' Institute ended its activities in Presov in the school year 1906/1907" (Podhajecka, 2009).

As the first in Slovakia, the gates of higher education in the field of preschool education were opened in Presov at the Faculty of Arts of Pavol Jozef Safarik University with its seat in Kosice in the school year 1973/1974. Later, it was possible to study preschool education in external form in Bratislava, Banska Bystrica, Trnava, and Ruzomberok (Podhajecka, 2009).

In Slovakia, a kindergarten teacher acquires qualification requirements by completing the relevant schools and obtaining a second-level university education, a first-level university education, or a full secondary vocational education. In the Czech Republic, a kindergarten teacher acquires a professional qualification through a university degree, higher vocational education or secondary education with a school-leaving examination.

According to Kotatkova (2009, p. 123), "... the preschool teaching study program gradually expanded to other pedagogical faculties at the end of the 1990 s and is currently represented in the study offer listat all faculties of education in the Czech Republic". Prucha (2009) presents a list of faculties preparing prospective teachers: the Faculties of Education in Prague, Olomouc, Ceske Budejovice, Ustinad Labem, Ostrava, and Hradec Kralove. Websitewww.vysokeskoly.cz includes also Brno, Plzen and the Faculty of Humanities of Tomas Bata University in Zlin. In Slovakia, there are the Faculties of Education at the University of Presov in Presov, Trnava University in Trnava, Constantine the Philosopher University in Nitra, Matej Bel University in Banska Bystrica, Comenius University in Bratislava, Catholic University in Ruzomberok and J. Selye University in Komarno.

"The teacher in Montessori education must be a person who knows this philosophy, he/she has studied Montessori's theoretical works, but that is not enough. If a teacher wants to be a "Montessori teacher", he/she must be internally identified with the education, philosophy and ideas of Maria Montessori" (Slovacek \& Minova, 2015, p. 147). The teacher in the Montessori school should undergo double training. According to Montessori (2001), theoretical preparation is very important and demanding. The student teacher must mould his/her personality, he/she must learn to be judicious, patient, observing, adaptable and persistent. The teacher should have a professional pedagogical education. The student teacher acquires such conditions by studying at universities (or high schools), preferably in pedagogical or teacher study programs. Such study includes (should include) pedagogical, psychological, didactic and methodological training. The second part of the training is training in Montessori education. The student teacher must be able to choose a suitable material, demonstrate its use. He/she must know the didactic material as well as the principles and theoretical base of Montessori education. The teacher does not teach the child, the child learns on his/her own. The teacher guides them on the path of life, directs their mental and physical activity.

The teacher in Montessori education must possess all the above-mentioned, traditionally recognized and generally valid competencies. However, the specificity and uniqueness of teaching, instruction and training in the intentions of Montessori education forces us to think about and design, formulate another, new and specific Montessori competence, which we define as "a summary of knowledge and understanding about Montessori education, the abilities to teach, instruct and train according to Maria Montessori and inner conviction and adjustment to the philosophy and ideas of Maria Montessori"'(Slovacek \& Minova, 2017a, p. 68; 2019). 


\section{Methods}

Within the research in formal education, we focused on the analysis of study programs of selected universities in Slovakia and the Czech Republic. Taking into consideration the topic of the paper, we focused on study fields and programs preparing kindergarten teachers.

\section{Relational research problem}

What possibilities do kindergarten student teachers have to learn about Montessori education during university vocational training (first and second level of university studies - Bc., Mgr.) in the Czech Republic and Slovakia?

The aim of our pedagogical research in formal education was to analyze the study plans of study programs at universities preparing kindergarten teachers in relation to teaching about Montessori education in the Czech Republic and Slovakia.

\section{Research sample}

The research sample consisted of Faculties of Education of six universities in the Czech Republic and Slovakia, which train kindergarten teachers. We analyzed the study plans of the relevant bachelor and master's study programs. The Czech Republic was represented by the Charles University in Prague, the Masaryk University in Brno, the University of Ostrava in Ostrava. Universities in Slovakia included the University of Presov in Presov, the Trnava University in Trnava and the J. Selye University in Komarno.

Table 1. Research sample $-1^{\text {st }}$ level of university studies

\begin{tabular}{|c|c|c|}
\hline country & university & Bc. \\
\hline \multirow{3}{*}{ 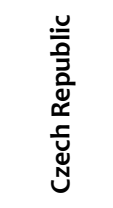 } & Charles University & $\begin{array}{l}\text { study program: Specialization in education } \\
\text { study field: Teaching in kindergartens }\end{array}$ \\
\hline & Masaryk University & $\begin{array}{l}\text { study program: Preschool and afterschool education } \\
\text { study field: Teaching in kindergartens }\end{array}$ \\
\hline & University of Ostrava & $\begin{array}{l}\text { study program: Teaching in kindergartens } \\
\text { study field: Teaching in kindergartens }\end{array}$ \\
\hline \multirow{3}{*}{$\begin{array}{l}\frac{\pi}{\frac{\pi}{0}} \\
\frac{0}{n} \\
\frac{0}{n}\end{array}$} & University of Presov & $\begin{array}{l}\text { study field: Preschool and elementary education } \\
\text { study program: Preschool and elementary education }\end{array}$ \\
\hline & Trnava University & $\begin{array}{l}\text { study field: Preschool and elementary education } \\
\text { study program: Preschool and elementary education }\end{array}$ \\
\hline & J. Selye University & $\begin{array}{l}\text { study field: Preschool and elementary education } \\
\text { study program: Preschool and elementary education }\end{array}$ \\
\hline
\end{tabular}

Table 2. Research sample $-2^{\text {nd }}$ level of university studies

\begin{tabular}{|c|c|c|}
\hline country & university & Mgr. \\
\hline \multirow{2}{*}{ 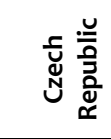 } & Charles University & $\begin{array}{l}\text { study program: Education } \\
\text { study field: Preschool-age education }\end{array}$ \\
\hline & University of Ostrava & $\begin{array}{l}\text { study program: Specialization in education } \\
\text { study field: Preschool-age education }\end{array}$ \\
\hline \multirow{2}{*}{$\frac{\frac{\pi}{8}}{\frac{0}{\pi}}$} & University of Presov & $\begin{array}{l}\text { study field: Preschool and elementary education } \\
\text { study program: Preschool education }\end{array}$ \\
\hline & Trnava University & $\begin{array}{l}\text { study field: Preschool and elementary education } \\
\text { study program: Preschool education }\end{array}$ \\
\hline
\end{tabular}




\section{Research tools (methods) and methodology}

In the research we used the methods of qualitative content analysis and comparative analysis, which Manak, Svec and Svec (2005) define as a method typically used in comparative pedagogy in the research of foreign education systems.

Firstly, we randomly selected six universities that formed the research sample. On the websites of faculties we searched for the study plans of the analyzed programs and fields and focused on subjects covering:

- education frameworks,

- alternative schools,

- innovative practices in education,

- history of education,

- reformatory pedagogy,

- and so alike.

We were interested in subjects with the content including also Montessori education explicitly mentioned in the content of the subject. We wrote down and systematized these subjects into tables containing the names and contents of subjects, study fields and programs. We were also interested in the numerical proportion of given subjects in relation to the number of compulsory subjects of the study program/field. We compared the data across the analyzed countries.

For economical reasons, we present individual universities by abbreviations in the tables: CUNI Charles University, MUNI Masaryk University, OSU University of Ostrava, UNIPO University of Presov in Presov, TRUNI Trnava University in Trnava, UJS J. Selye University in Komarno.

The analysis of the study plans of individual study programs was carried out in October and November 2018, using publicly available information on the websites of individual faculties of selected universities. It was desirable to search in detail and analyze the various ways of presenting the contents of subjects in individual study programs, either in the form of information systems or as electronic documents published on the websites of faculties and departments.

\section{Findings}

We analyzed the formal education in the first and second level of university studies separately. The bachelor study program (training for teaching in kindergartens) is provided by all the faculties in the sample. The master's study program is provided by two faculties (from our sample) in the Czech Republic and two faculties (from our sample) in Slovakia. 
Table 3. Formal education - first level of study - Slovakia

\begin{tabular}{|c|c|c|c|}
\hline \multicolumn{4}{|c|}{ SLOVAKIA - Bc. } \\
\hline university & program and field & subject & content \\
\hline UNIPO & $\begin{array}{l}\text { study field: Preschool and } \\
\text { elementary education } \\
\text { study program: Preschool and } \\
\text { elementary education }\end{array}$ & $\begin{array}{l}\text { Philosophical, social and } \\
\text { psychodidactic } \\
\text { cornerstones of education }\end{array}$ & $\begin{array}{l}\text { Philosophical base of } \\
\text { alternative schools (Maria } \\
\text { Montessori, R. Steiner) }\end{array}$ \\
\hline TRUNI & $\begin{array}{l}\text { study field: Preschool and } \\
\text { elementary education } \\
\text { study program: Preschool and } \\
\text { elementary education }\end{array}$ & & - \\
\hline UJS & $\begin{array}{l}\text { study field: Preschool and } \\
\text { elementary education } \\
\text { study program: Preschool and } \\
\text { elementary education }\end{array}$ & $\begin{array}{l}\text { Basics of alternative } \\
\text { education }\end{array}$ & $\begin{array}{l}\text { Formation of alternative } \\
\text { schools in } 1^{\text {st }} \text { half of } 20^{\text {th }} \\
\text { century (Waldorf, Jena } \\
\text { Plan, Dalton, Freinet, } \\
\text { Montessori) }\end{array}$ \\
\hline
\end{tabular}

As we present in Table 3, study at the Faculty of Education of the University of Presov in Presov provides students with information about the philosophical base of alternative schools, covered by the subject Philosophical, social and psychodidactic cornerstones of education. At the faculty of the University of Komarno it is the subject Basics of alternative education. In the study plan of the Faculty of Education of Trnava University we did not find an explicit mention of Montessori education or alternative education in any of the compulsory subjects. Hopefully the teachers introduce alternative education in their subjects so that graduates of the bachelor study program from Trnava University as qualified employees of kindergartens and experts for preschool education have at least an idea of such methods and concepts. These can be used with children with special educational needs, who are now integrated into the collective of intact children in accordance with the trend of inclusion and integration. Montessori education offers possibilities, at least materially, to help such children through education in kindergarten (Slovacek \& Minova, 2017b).

Table 4. Formal education - first level of study - the Czech Republic

\begin{tabular}{|c|c|c|c|}
\hline \multicolumn{4}{|c|}{ THE CZECH REPUBLIC - Bc. } \\
\hline university & program and field & subject & content \\
\hline \multirow[b]{2}{*}{ CUNI } & \multirow{2}{*}{$\begin{array}{l}\text { study program: } \\
\text { Specialization in education } \\
\text { study field: Teaching in } \\
\text { kindergartens }\end{array}$} & $\begin{array}{l}\text { History of preschool } \\
\text { education }\end{array}$ & $\begin{array}{l}\text { Personalities and concepts of the } \\
\text { reform movement abroad }\end{array}$ \\
\hline & & $\begin{array}{l}\text { Alternative programs } \\
\text { in theory and practice }\end{array}$ & $\begin{array}{l}\text { Montessori education, Waldorf } \\
\text { education, Reggio Emilia, Start } \\
\text { together ... }\end{array}$ \\
\hline MUNI & $\begin{array}{l}\text { study program: Preschool } \\
\text { and after school education } \\
\text { study field: Teaching in } \\
\text { kindergartens }\end{array}$ & $\begin{array}{l}\text { Introduction to } \\
\text { education and } \\
\text { psychology }\end{array}$ & $\begin{array}{l}\text { Pedagogical reformism and the origin } \\
\text { of alternative schools. Development } \\
\text { of viewing the child from the } 19^{\text {th }} \\
\text { century (Dewey, Key, Decroly, } \\
\text { Montessori, Steiner, Parkhurst, etc.) }\end{array}$ \\
\hline osu & $\begin{array}{l}\text { study program: Teaching in } \\
\text { kindergartens } \\
\text { study field: Teaching in } \\
\text { kindergartens }\end{array}$ & $\begin{array}{l}\text { Comparative } \\
\text { pedagogy and history }\end{array}$ & $\begin{array}{l}\text { Origin, development, functions and } \\
\text { types of alternative education for } \\
\text { preschool children }\end{array}$ \\
\hline
\end{tabular}

In Table 4 we present an overview of subjects covering Montessori education in the study fields and programs of individual faculties. Masaryk University and the University of Ostrava teach about alternative approaches to education in the subjects Introduction to education 
and psychology and Comparative pedagogy and history. Both subjects are compulsory. Charles University teaches about alternative and reform systems in the subjects History of preschool education and Alternative programs in theory and practice.

In 2017 we published a similar survey. At that time, there were the subjects Basics of education (Historical development of preschool education), Preschool education in the concepts of pedagogical thinkers (Comenius, Rousseau, Frobel, Svoboda, Montessori and others), Alternative approaches in kindergarten, Nature and principles of alternative schools (Montessori, Dalton School, Waldorf School) included in the study plan of Masaryk University (Slovacek \& Minova, 2017c).

The analysis of study plans in study programs for the first level of university study revealed the presence of subjects about Montessori education / alternative education at the faculties in Prague, Brno, Ostrava, Presov and Komarno. Such teaching content is absent in Trnava.

In the bachelor study program, the study plan of the Faculty of Education at the University of Presov has 37 compulsory subjects, of which one (2.70\%) is about Montessori education. The faculty in Trnava has 26 compulsory subjects and none of them (0\%) covers Montessori. At the University of Komarno, students study Montessori education in one subject (2.27\%) out of 44 compulsory subjects. Faculties in the Czech Republic generally have more compulsory subjects. Charles University focuses on alternative concepts and Montessori education in two subjects (3.33\%) out of the total number of 60 compulsory subjects. The faculty in Brno has one subject $(1.82 \%)$ out of 55 and the Faculty of Education at the University of Ostrava has also one subject (2.04\%) out of the total number of 49 that serve our purpose.

Table 5. Formal education - second level of study - Slovakia

\begin{tabular}{|l|l|l|l|}
\hline \multicolumn{3}{|l|}{ SLOVAKIA - Mgr. } \\
\hline university & program and field & subject & content \\
\hline UNIPO & $\begin{array}{l}\text { study field: Preschool and } \\
\text { elementary education } \\
\text { study program: Preschool } \\
\text { education }\end{array}$ & $\begin{array}{l}\text { Current trends in } \\
\text { education }\end{array}$ & Alternative approaches in education \\
\hline \multirow{3}{*}{ TRUNI } & $\begin{array}{l}\text { study field: Preschool and } \\
\text { elementary education } \\
\text { study program: Preschool } \\
\text { education }\end{array}$ & $\begin{array}{l}\text { Early childhood } \\
\text { learning } \\
\text { environment }\end{array}$ & $\begin{array}{l}\text { Innovative early } \\
\text { childhood } \\
\text { in alternative approaches to education and } \\
\text { its relation to the development of children } \\
\text { (Montessori education, Waldorf school) }\end{array}$ \\
\cline { 3 - 5 } & $\begin{array}{l}\text { education } \\
\text { programs }\end{array}$ & $\begin{array}{l}\text { Traditional and alternative approaches to } \\
\text { education in kindergartens, primary } \\
\text { schools and informal education, analysis of } \\
\text { European trends }\end{array}$ \\
\hline
\end{tabular}

Of the three Slovak universities analyzed, just two provide second-level education in the Preschool education program: University of Presov and Trnava University. The Faculty of Education in Presov covers alternative approaches in education within the subject Current trends in education. The existence of this subject confirms our statements about the topicality of the examined issue. The Faculty of Education in Trnava compensates for the zero representation of the topic in the bachelor study program and provides two subjects on alternative approaches in the master's study program, namely Early childhood learning environment and Innovative early childhood education programs. We consider this fact to be positive, as it is the quantitatively highest representation of subjects of this nature in the comparison of all four faculties. It is only pity that in Trnava we do not find a single subject of 
such specialization in the bachelor study program, which also (even without the second level of study) qualifies the student as a qualified professional.

Table 6. Formal education - second level of study -the Czech Republic

\begin{tabular}{|l|l|l|l|}
\hline \multicolumn{2}{|l|}{ ČSKA REPUBLIKA - Mgr. } \\
\hline university & program and field & subject & content \\
\hline CUNI & $\begin{array}{l}\text { study program: Education } \\
\text { study field: Preschool-age } \\
\text { education }\end{array}$ & $\begin{array}{l}\text { Selected chapters from } \\
\text { pedagogy and } \\
\text { preschool education }\end{array}$ & $\begin{array}{l}\text { The base of reform pedagogy and the } \\
\text { origin of alternative concepts and } \\
\text { programs }\end{array}$ \\
\hline OSU & $\begin{array}{l}\text { study program: } \\
\text { Specialization in education } \\
\text { study field: Preschool-age } \\
\text { education }\end{array}$ & $\begin{array}{l}\text { Pedagogy - selected } \\
\text { issues of education }\end{array}$ & $\begin{array}{l}\text { Models of education. Reform, } \\
\text { alternative models in education and } \\
\text { current innovative foreign models of } \\
\text { education }\end{array}$ \\
\hline
\end{tabular}

Table 6 presents the representation of subjects covering alternative education in the study plan of the second level of study at the Faculty of Education at Charles University and the Faculty of Education at the University of Ostrava. The Faculty of Education at Masaryk University does not provide a second level of study for kindergarten teachers. At Charles University, students get acquainted with the base of reform pedagogy and the origin of alternative concepts and programs in the subject Selected chapters from pedagogy and preschool education. At the faculty in Ostrava, the subject Pedagogy - selected issues of education covers the models of education, reform, alternative and current foreign models of education. In both cases, the content of teaching is reform pedagogy and alternative models and programs, including Montessori education as the basic concept.

The study plan for the second level of university study of preschool education at the faculty in Presov has 25 compulsory subjects, of which one (4\%) also covers Montessori education. The faculty in Trnava teaches the abovementioned two subjects (6.67\%) on the education that is in the center of our interest together with 15 other subjects. The study programs of the analyzed Czech faculties of education have more than 30 compulsory subjects. Charles University has 34 , of which one $(2.94 \%)$ on Montessori education, the University of Ostrava has 33, of which one $(3.03 \%)$ subject is related to our topic.

\section{Ways of non-formal and informal education}

Another option for student teachers, but also for in-service teachers, is non-formal and informal learning. In Slovakia, the Slovak Montessori Association offers a certificated course accredited by the Ministry of Education, Science, Research and Sports of the Slovak Republic. The course takes place in Bratislava, its duration is 368 hours and the cost is 1,610 EUR $(1,817$ USD). The Association also offers the first certificated course Montessori Teacher at Primary School, consisting of three separate year long courses and focusing on teachers at primary schools. The cost per one courseis 1,490 EUR (1,682 USD). There are several possibilities in the Czech Republic, namely: the Montessori Society Certificated Course in Prague, of duration 490 hours and costing 1951 EUR (2,202 USD); the Yearlong Certificated Course of the Montessori Academy Biberkor, which is an integrated holistic program that combines traditional basic AMI (Association Montessori Internationale) courses (3-6, 6-12, 12-16 years) and at the same time prepares for the effective integration of children with special educational needs. The cost of the course is 3,298 EUR (3,723 USD) (www.erudio-montessori.cz). Another option is the education at AMI Prague. Interesting, accessible non-formal Montessori education seminars are led by MVDr. Eva Starkova both in the Czech Republic and in Slovakia. The 
training, divided into modules, takes the form of 8 hour meetings. One module, one seminar costs 33 EUR ( 37 USD) and the content is a brief theory and practical examples of working with the material, experiential learning of participants and methodological material. Seminars are held in the Czech Republic in Prague, Olomouc or Ceske Budejovice, in Slovakia in Bratislava, Humenne, Kosice, Vranov nad Toplou, Banska Bystrica and in other cities according to the current offer.

None of the mentioned non-formal types of education provide graduates with the qualification prerequisites for the work as a kindergarten teacher.

Informal education includes books and magazines. There are 31 books available in Slovak and Czech bookstores (physical shops and e-shops), of which 10 are Slovak and Czech in origin, 21 translated. In 2019 we analyzed 3226 articles in professional pedagogical Slovak and Czech journals dealing with preschool and elementary pedagogy, namely: Comenius, Master: reflection on primary and pre-primary education, Pedagogical orientation, Pedagogy: Journal for sciences of education, e-Pedagogium, Our school, Preschool education, Pedagogika.sk, Pedagogical views, and Journal of Pedagogy. We analyzed all journals published since 2010 or since their first issues if first published after 2010. We analyzed articles with titles explicitly naming Montessori education, i.e., the articles about Montessori. In the case of the Preschool education journal we analyzed the issues and volumes published by the current publisher and available on the journal's website. Since the survey conducted in 2017 (Slovacek, 2017/2018), not a single article has been added. Even today we find articles: Slovacek and Minova (2016/2017) Montessori education and its role in the preparation of a child for entering primary school; Slovacek (2015/2016) The relationship between educator and learner according to Maria Montessori in the magazine Our school. The topic of Montessori education in primary school is described by Kratochvilova: Montessori not only in the primary school, published in Comenius journal in 2014, which makes up $0.09 \%$ of the number of 3226 analyzed articles. We are constantly trying to improve this situation, from 2015 to 2020 we have published 11 articles in anthologies and journals in Slovakia, Poland, the Ukraine and Belarus.

\section{Discussion and conclusion}

In Slovakia and the Czech Republic, there are ways for undergraduate kindergarten teachers to learn about Montessori education as part of acquiring a qualification at pedagogical faculties. These are not subjects focused only on the Montessori education, but usually subjects about the philosophical basis of education, alternative and reform concepts of education, training and instruction, where Montessori education is covered marginally, rather informatively. Bachelor study program students get in touch with Montessori education at five faculties, excluding the Faculty of Education at Trnava University in Trnava, which, as mentioned above, impoverishes the profile and expertise of the kindergarten teacher. In master's studies, Montessori education is taught at all four faculties providing the study of kindergarten teaching. At this level of study the faculty in Trnava compensates for the absent subject in terms of number.

Based on the examined relational problems defined in our research it can be stated that the bachelor study programs at the analyzed Czech faculties of education cover Montessori education, what is perceived as an advantage. Czech universities teach about Montessori at both levels of education at all analyzed faculties in six subjects, Slovak universities in five subjects. 
An independent study of Montessori education as a study field or as a university subject does not yet exist in Slovakia or the Czech Republic.

\section{References}

Kosova, I., Almasi Korenova, Z. \& Cinova, E. (2013). Pomoz mi, aby som to urobil sam. [Help me so that I can do it by myself]. Bratislava, Slovensko: Metodicko - pedagogicke centrum.

Kotatkova, S. (2009). Vysokoskolske vzdelavani ucitelek materskych skol. [University training of kindergarten teachers]. In J. Kancir \& V. Zelova (Eds.), Priprava ucitelov v procese skolskych reforiem (pp. 121-126). Presov, Slovensko: Pedagogicka fakulta, Presovska univerzita v Presove.

Kozelkova, M. (2013). Poruchy vyssich zrakovych funkcii deti s detskou mozgovou obrnou. Montessori terapia. [Disorders of higher visual function in children with cerebral palsy. Montessori therapy]. Trnava/Krakow, Slovensko/Polsko: Filozoficka fakulta Trnavskej univerzity v Trnave/Towarzysteo Slowakow w Polsce.

Lipnicka, M. (2011). Predskolska pedagogika nielen pre ucitelov. [Preschool education not only for teachers]. Presov, Slovensko: Rokus.

Manak, J., Svec, S. \& Svec, V. (2005). Slovnik pedagogicke metodologie. [Dictionary of pedagogical methodology]. Brno. Cesko: Masarykova univerzita.

Matsumoto, D. (Ed.). (2009). The Cambridge Dictionary of Psychology. Cambridge, UK: Cambridge University Press.

Minova, M. (2012). Manazment materskej skoly. [Kindergarten management]. Presov, Slovensko: Pedagogicka fakulta Presovskej univerzity v Presove.

Montessori, M. (2001). Objevovani ditete. [The discovery of the child]. Praha, Cesko: Nakladatelstvi svetovych pedagogickych smeru.

Montessori, M. (2007). From Childhood to Adolescence. Amsterdam, Netherlands: MontessoriPierson Publishing Company.

Pajdlhauserova, E. (2009). Od detskych opatrovni k materskym skolam v sustave skol. [From childcare to kindergartens in the school system] In E. Gasparova \& M. Minova (Eds.), Od detskej opatrovne kmaterskej skole (pp. 65-71). Banska Bystrica, Slovensko:Slovensky vybor OMEP, Spolocnost pre predskolsku vychovu.

Petlak, E., Valabik, D. \& Zajacova, J. (2009). Vyucovanie - mozog - ziak. [Instruction - brain leader]. Bratislava, Slovensko: IRIS.

Podhajecka, M. (2009). Dieta a svet v kontexte vysokoskolskej pripravy ucitelov. [Child and Word in the kontext of undergraduate teacher training]. In J. Kancir \& V. Zelova (Eds.), Priprava ucitelov $v$ procese skolskych reforiem (pp. 24-38). Presov, Slovensko: Pedagogicka fakulta, Presovska univerzita v Presove.

Prucha, J. (ed.). (2009). Pedagogicka encyklopedie. [Encyclopedia of education]. Praha, Cesko: Portal.

Rajovic, R. (2018). NTC System uceni. Metodicka prirucka pro praci s NTC metodou. Cast 2 -vek 48 roku. Jak uspesne rozvijet IQ ditete hrou. [NTC leasing system. Methodical manual for work with NTC method. Part 2 - age 4-8 years. How to successfully develop IQ of a child through play]. Praha, Cesko: Mensa Ceske republiky. 
Rydl, K. (1999). Principy a pojmy pedagogiky Marie Montessori (ucebni pomucka pro verejnost).[Principles and concepts of Montessori education (teaching aid for the public)]. Praha, Cesko: Nakladatelstvi Public History Praha.

Rydl, K. (2007). Metoda Montessori pro naše dite: Inspirace pro rodice a dalsi zajemce.Pardubice, Cesko: Filozoficka fakulta Univerzity Pardubice.

Sebestova, V., \& Svarcova, J. (1996). Maria Montessori - aktualne. [Maria Montessori currently]. Praha, Cesko: Vyssi pedagogicka skola a stredni pedagogicka skola a gymnazium v Praze.

Slovacek, M. (2015/2016). Vztah edukanta a edukatora podla Marie Montessoriovej. [Teacher student relationship according to Maria Montessori]. Nasa skola, (19)7, 12-19.

Slovacek, M. (2017/2018). Pedagogika Marie Montessoriovej vodbornych periodikach na Slovensku a v Cesku. [Montessori education in Slovak and Czech professional journals]. Nasa skola, (21)9-10, 32-38.

Slovacek, M.\& Minova, M. (2015). „Zabudnuta?” - Pedagogika Marie Montessori. [Forgotten? Montessori education]. In J. Zolnova \& T. Dubayova (Eds.), Student na ceste $k$ praxi IV (pp. 145-152). Presov, Slovensko: Presovska univerzita v Presove, Pedagogicka fakulta.

Slovacek, M.\& Minova, M. (2017a). Pedagogika Marie Montessoriovej - terminologicke minimum alebo Montessori pedagogika pre kazdeho. [Montessori education - Terminological minimum or Montessori education for all]. Presov, Slovensko: Rokus.

Slovacek, M.\& Minova, M. (2017b). Moznosti vyuzitia materialu Marie Montessoriovej v edukacii deti so specialnymi vychovno-vzdelavacimi potrebami v predprimarnej skole. [Ways of using Montessori materials when teaching preschool children with special educational needs]. In R. Bernatova \& T. Nestorenko (Eds.), Vzdelavanie a spolocnost II. (pp. 36-46). Prešov, Slovensko: Presovska univerzita v Presove.

Slovacek, M.\& Minova, M. (2017c). Ucitel (materskej skoly) v pedagogike Marie Montessoriovej a jeho vzdelavanie. [Preschool teacher in Montessori education and his training]. In R. Bernatova \& T. Nestorenko (Eds.), Vzdelavanie a spolocnost II. (pp.139-147). Presov, Slovensko: Presovska univerzita v Presove.

Slovacek, M.\& Minova, M. (2019). Pedagogika Marie Montessoriovej z pohladu teorie a praxe.[Montessori education from theory and practice]. Presov, Slovensko: Rokus.

Slovacek, M.\& Minova, M. (2016/2017). Pedagogika Marie Montessoriovej a jej miesto v priprave dietata na vstup do primarnej skoly. [Montessori education and its role in preparing a child for primary school]. Nasa skola, (20) 8, 14-23.

Syslova, Z. (2017). Ucitel $v$ predskolnim vzdelavani a jeho priprava na profesi. [Teacher in preschool education and his training]. Brno, Cesko: Masarykova univerzita.

Tothova, R., Kostrub, D. \& Ferkova, S. (2017). Ziak, ucitel a vyucba (vseobecna didaktika pre studentov ucitelstva). [Student, teacher and instruction: General didactics for student teachers]. Presov, Slovensko: Rokus.

Zelina, M. (2000). Alternativne skolstvo. [Alternative school]. Bratislava, Slovensko: IRIS.

Zelinkova, O. (1997). Pomoz mi, abych to dokazal. [Help me so that I can do it]. Praha, Cesko: Portal.

www.statpedu.sk

www.erudio-montessori.cz 


\section{Biographical notes:}

Ph Dr. Paed Dr. Matej Slovacek is an expert in preschool education. He focuses on Montessori education and pedagogical diagnostics in theory, practice and research. He is a member of the Slovak OMEP Committee and the Association of Preschool Education in the Czech Republic. A graduate of the University of Presov in Presov, Charles University in Prague and Matej Bel University in Banska Bystrica.

Paed Dr. Monika Minova, PhD. is a member of the Department of Preschool and Elementary Education and Psychology at the Faculty of Education of the University of Presov in Presov. Her expertise is preschool education and didactics, alternative approaches in education, kindergarten management, pedagogical diagnostics and cooperation of school with institutions. She is the chairwoman of the Slovak OMEP Committee. A graduate of the Pavol Jozef Safarik University in Kosice and the University of Presov in Presov. 